\title{
REM SLEEP REDUCES THE POSTPRANDIAL INCREASE OF HEAT PRODUCTION IN PIGLETS
}

\author{
V. KOTRBÁČEK, Z. HÖNIG
}

Department of Physiolosy, University of Veterinary Sciences, 61242 Bmo

Received November 24, 1988

Abstract

K o t r b á ¿ e k V., Z. H ö n i g: REM Sleep Reduces the Postprandial Increase of Heat Production in Piglets. Acta vet. Brno, 58, 1989:303-311.

The changes of heat production (HP) in 3 to 5-day-old Large White piglets sleeping in a thermoneutral environment were measured over a 60 -min period after food intake. The measurements were carried out in a group of 10 piglets fed orally and in a group of 10 tube-fed piglets. To avoid any effect of motor activity on HP, the diet was administered in the metabolic respiratory chamber to completely reposeful piglets. The quality and quantity of the administered feed was the same for both groups.

Postprandial HP in piglets fed orally significantly increased already within the first 10 minutes after feeding. This early increase was not observed in piglets fed through the tube, what showed the effect of sensory stimulation of sympathetic nervous system on the course of early postprandial HP.

The postprandial HP was also affected by the character of sleep of the experimental piglets; during REM sleep the HP was regularly lower in comparison to NREM sleep. However, this differences were significant only in piglets fed orally.

The mechanism of this energy-saving effect of REM sleep apparently lies in its inhibitory effect on the sympathetic nervous system stimulated by food intake.

Sleep, heat production, food intake, $R Q$

That heat production (HP) increases after food intake is a phenomenon known since the last century. In spite of this fact it has recently been given unprecedented attention. For example, the increased so-called regulating thermogenic effect of luxury consumption in rats and mice has often been discussed in scientific literature ( $R$ o t h we 11 and $S t o c k s$ 1978, 1982, 1983; Tra y h u r n et al; 1982; A ndrew and Do n ne 1982; Herve y and T o b i n 1983 and others). The fact that this phenomenon has not always been successfully proved suggests that there still exist other factors responsible for the level of postprandial HP. Studies dealing with the effect of the palatability of ingested food on postprandial thermogenesis drew attention to une such factor. Two same feeds were given to experimental human subjects; postprandial heat production was higher in humans given more palatable and attractive food ( $\mathrm{e} \mathrm{B} \mathrm{l}$ a n c and B r o n d e l 1985). These authors proved the association between the thermogenic effect of food and the activation of the autonomic nervous system via the perceptions during eating. The effect of palatability of the consumed food was evident particularly in the initial phase, called cephalic phase, whereas the second phase called digestive, is related to the processes of digestion proper ( $\mathrm{D}$ i a $\mathrm{m}$ o $\mathrm{n} \mathrm{d}$ et al. 1985). In similar experiments with dogs fed orally and through an intragastric tube, $D$ i a m o n d and L e B l a n c (1987ab) convincingly proved the importance of catecholamines for starting the cephalic phase, and also that both branches of the autonomic nervous system are involved in postprandial thermogenesis.

Our previous studies have suggested that the level of HP in piglets can also change during sleep ( $\mathrm{K}$ o t r b a $\subset$ e $\mathrm{k}$ and $\mathrm{H}$ ö $\mathrm{n} \mathrm{ig} \mathrm{1989a.} \mathrm{In} \mathrm{contrast} \mathrm{to} \mathrm{the} \mathrm{NREM} \mathrm{sleep} \mathrm{period,} \mathrm{HP}$ decreases during REM sleep, both in a cool and thermoneutral environment. The diferences were particularly marked shortly after food intake. Further studies were therefore conducted to find, if there is any demonstrable relationship between REM sleep and the thermogenic effect of food. 


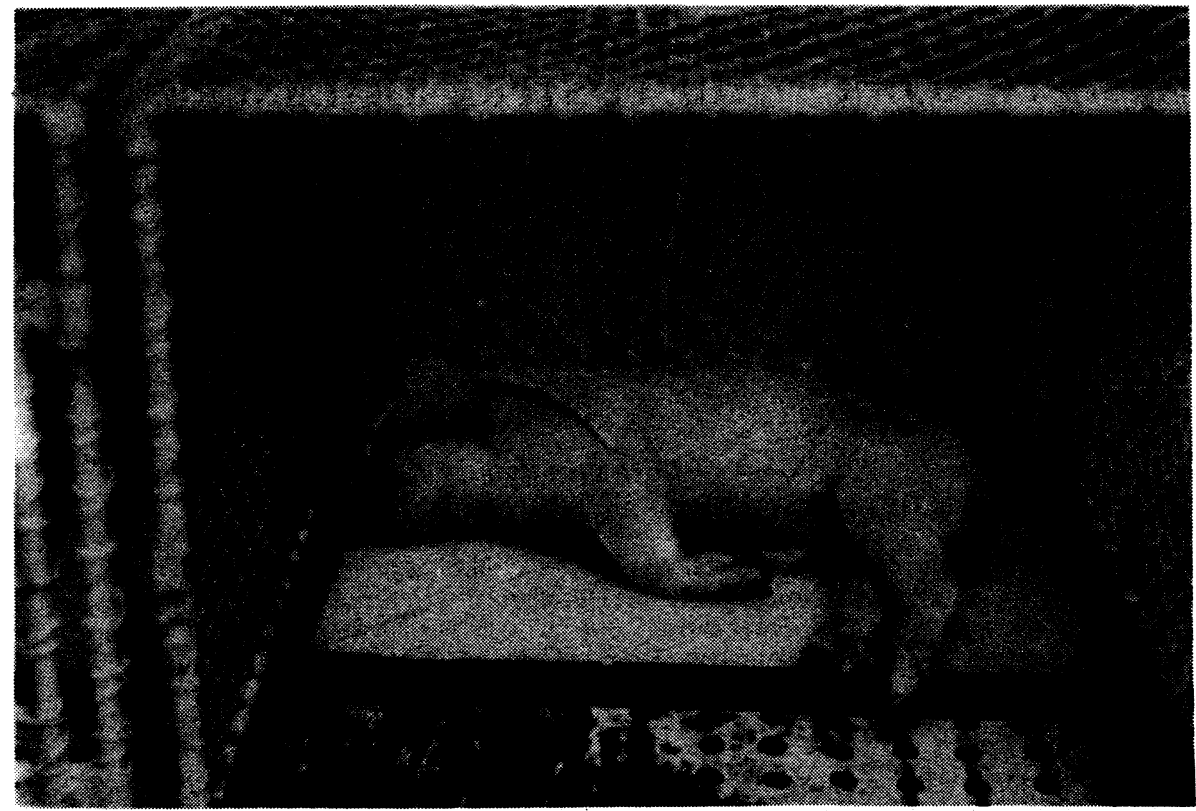

Fig. 1 Outlet and fixation of gastric tube

\section{Materials and Methods}

Two groups of 10 three to five-day-old Large White piglets kept in the laboratory from the first day of life were used in the present study.

A polyethylene tube $4.0 \mathrm{~mm}$ in diameter was inserted into the stomachs of the piglets of the first group at the age of one day. The tube was fitted with a plastic ending, easing passage through the pharynx and oesophagus. The other end of the tube was exteriorized behind the molars to the lateral part of the head where it was fixed to the skin with a suture (Fig. 1). It was further lead on the skin surface ot the dorsal part of the neck and between the ear lobes to the back where another suture was used to fix it to the skin. A stopper was adjusted to the 5-7 cm long free end. Correct insertion of the tube was checked with an X-ray apparatus. The piglets adapted well to the tube employed for administration of liquid diet (prepared from the commercial dry milk mixture „Selasan ${ }^{\circ}$ ) into the stomach. The diet was prepared by dissolving 1 weight unit of Selasan in 4 parts of boiled distilled water cooled to $40^{\circ} \mathrm{C}$. This mixture was then thoroughly mixed and cooled to $38^{\circ} \mathrm{C}$ before administration. The other group was bottle-fed the same diet.

The experimental procedure was as follows: After a night rest and 12 hours of fasting the piglets were placed in a metabolic respiratory chamber with the floor heated to $38^{\circ} \mathrm{C}$. The cooling effect of the chamber was maintained within a range of $160-180$ W.m-2 as measured by the electric dynamic katathermometer sensor according to $\mathrm{C}$ e $\mathbf{s} \mathrm{n}$ e $\mathbf{k}$ and $\mathrm{N} \mathrm{o} \mathrm{v}$ á $\mathbf{k}$ (1971). These thermal conditions were in accordance with previous experiments and the experimental piglets calmed down virtually immediately and fell asleep. Spirolyt II was used to measure the values of $\mathrm{O}_{2}$ and $\mathrm{CO}_{2}$; the level of $\mathrm{HP}$ of the hungry and peacefully sleeping piglets was found to be resting. Within $30 \mathrm{~min}$ of these measurements, the 3 to 5-day-old piglets of the first group were given $55.0 \mathrm{ml}$ of the diet into the stomach through the tube. This quantity corresponded to the average dose spontaneously taken by the piglets of the 2 nd group. Tube feeding was performed from outside of the chamber. Thus the sleeping piglets were not disturbed during feeding, and the effect of movement on the energy metabolism was completely eliminated. It should, however, be mentioned that during the infusion proper, which lasted for about one minute, sleep was usually interrupted for a short moment (opening of the eyes) and then continued again. From the moment of infusion, the $\mathrm{O}_{2}$ consumption and $\mathrm{CO}_{2}$ production were measured over a 60 -min period. 
The procedure in the second goup was the same. After the piglets fell asleep in the metabolic chamber and their resting metabolism was measured, they were gently woken and through a special service hatch were fed in the chamber. The feeding lasted less than one minute. Afterwards nearly each piglet fell asleep again. Measurements from piglets showing an increased activity during feeding or during the experiment were eliminated.

The $\mathrm{O}_{2}$ consumption and $\mathrm{CO}_{2}$ production were determined every minute, as well as the character of sleep. REM sleep was recorded visually on the basic of characteristic exernal ma-

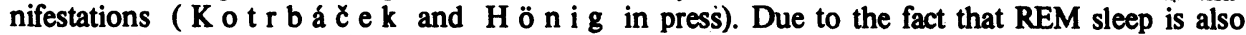
accompanied by changes in the gas exchange, its onset and termination could be determined precisely from the $\mathrm{O}_{2}$ and $\mathrm{CO}_{2}$ records. Postprandial $\mathrm{HP}$ and $\mathrm{RQ}$ was determined one hour after food intake and was evaluated as the average value of six subsequent 10 -min periods.

The significance of differences between the two groups fed in a different way and between the sleep periods were assessed by Students' t-test.

\section{Results}

Postprandial HP in piglets fed orally rapidly increased within the first 10 minutes after feeding $(P<0.01)$ and reached its peak value (Fig. 2). The following decline was gradual so that towards the end of the experimental period the effect of feed on HP was still significant. In tube-fed piglets there was no initial increase in the postprandial HP (Fig. 2). HP did not increase significantly until between 10 and 20 min after food intake $(P<0.01)$; later it showed no changes. The differences in postprandial HP between the two groups fed in different ways were statistically highly significant only within the first $10 \mathrm{~min}$ after feeding.

The level of postprandial HP also changed in connection with the sleep. Compared with NREM sleep, HP was regularly lower in the period of REM

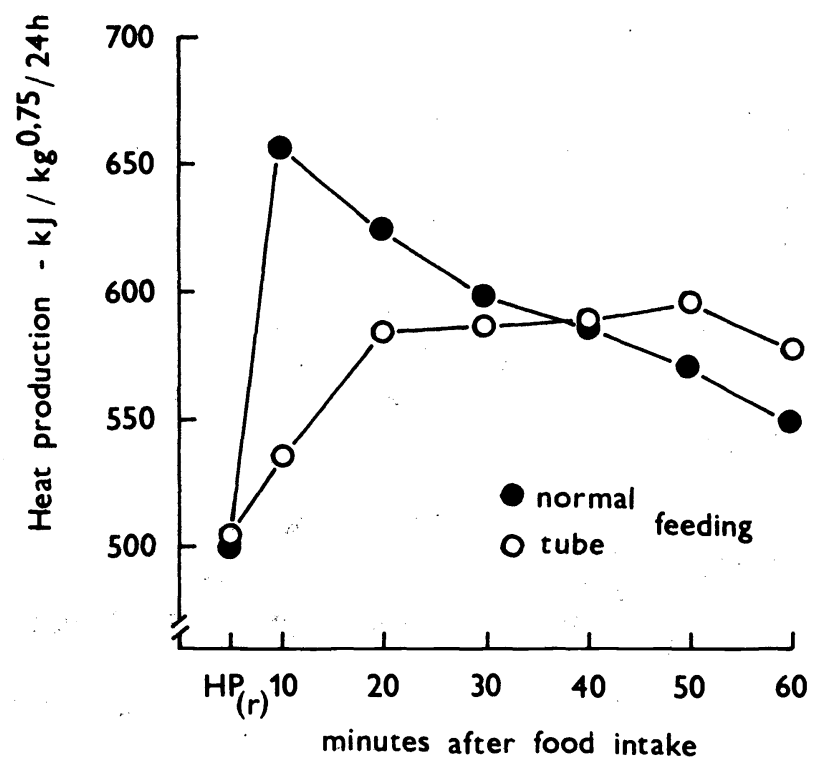

Fig. 2 The effect of mode of feeding on postprandial heat production in piglets 
sleep in both groups of piglets (Figs. 3 and 4). However, the statistical significance of these differences was found only in piglets fed per os in the period - of 40 minutes after food intake. Fig 3 also shows the high frequency of REM episodes in the overall sleep of this period.

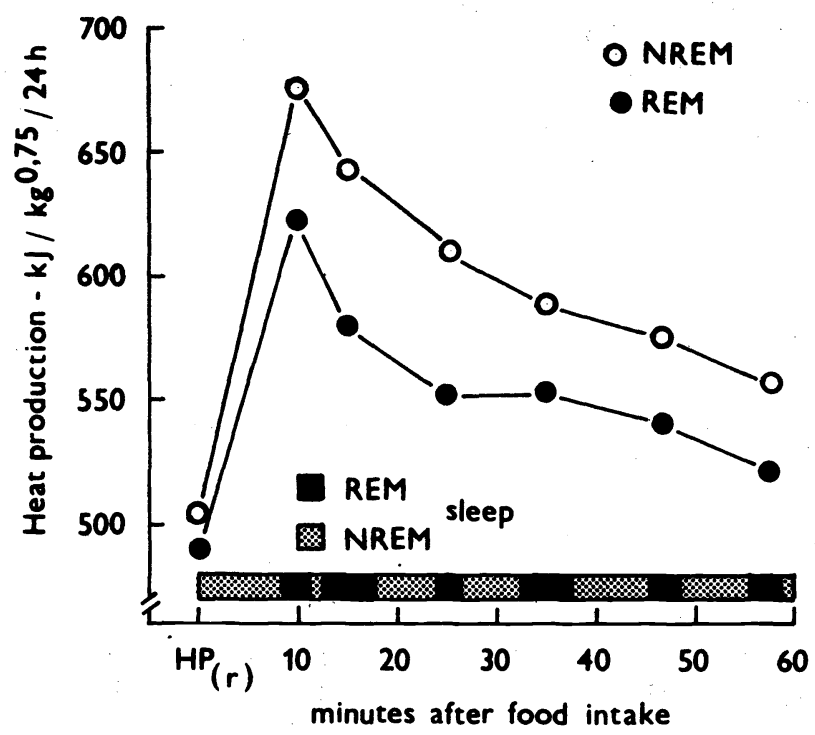

Fig. 3 The effect of NREM and REM sleep on the level of postprandial heat production in piglets fed orally

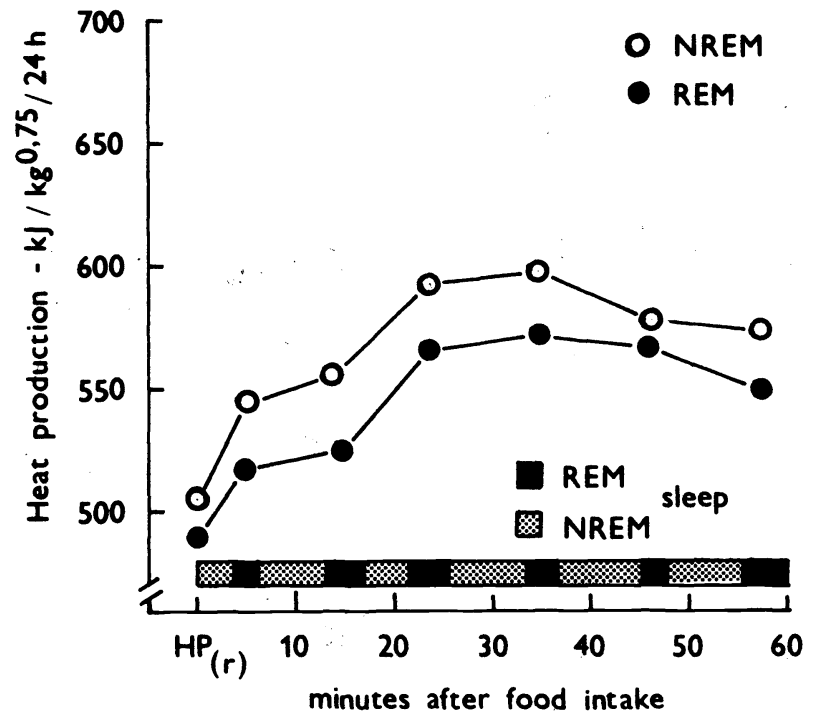

Fig. 4 The effect of NREM and REM sleep on the level of postprandial heat production of tube-fed piglets 
Figs. 5 and 6 show the effect of REM sleep on the decline in HP; shown are the minute changes of $\mathrm{O}_{2}$ consumption of two piglets after bottle feeding. The onset of the REM period is always accompanied by a decline in $\mathrm{O}_{2}$ consumption.

The value of RQ after food intake changed in the same way as HP (Fig. 7). In piglets fed orally it increased rapidly and reached its peak value $(P<0.05)$ within the first 10 minutes after feeding whereas in the group fed through the tube it did not change significantly during this period. Thus the difie-

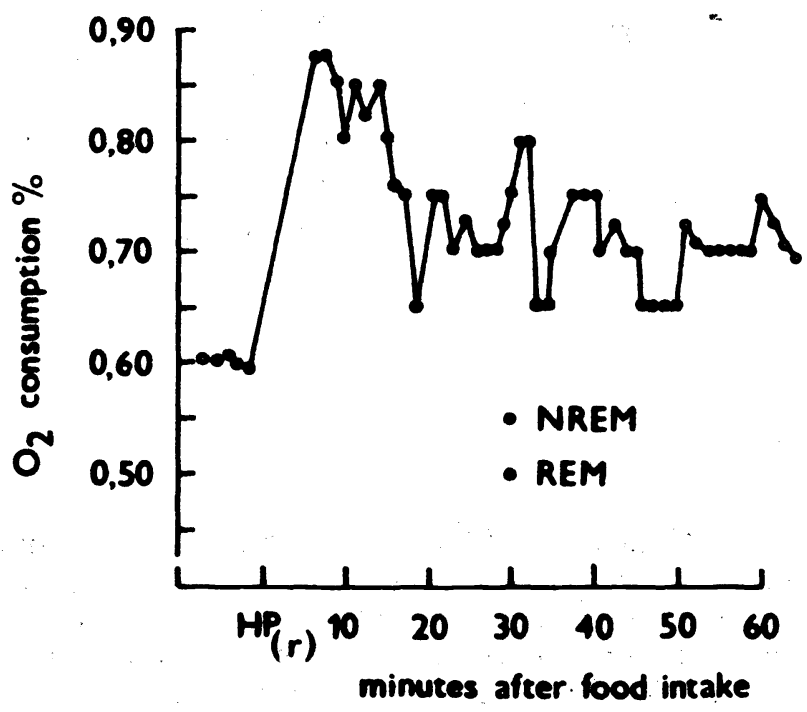

Fiz 5 The effect of REM sleep on the decline of postprandial $\mathrm{O}_{2}$ consumption of a 3-day-old piglet

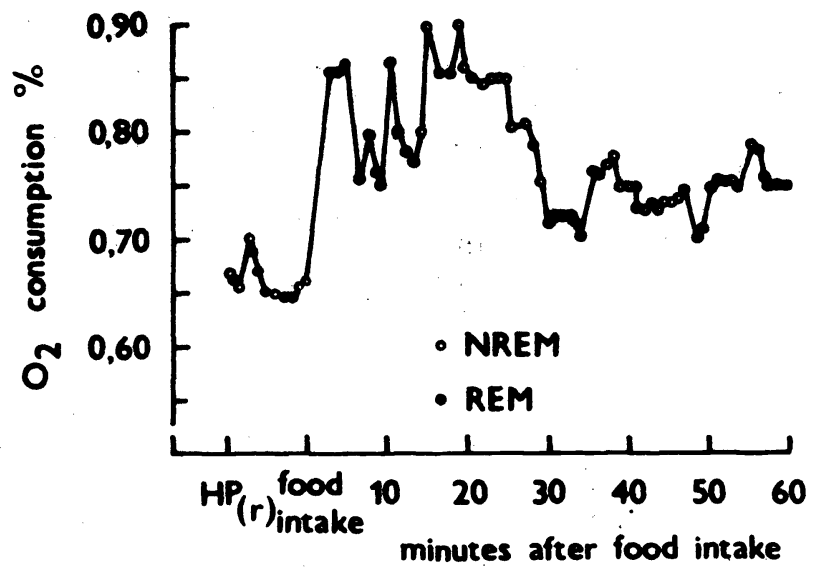

Fig. 6 The effect of REM sleep on the decline of postprandial 0 consumption of a 5-day-old pigla 
rences between the two groups became significant. Howerer, between $10-20 \mathrm{~min}$ after food intake, when RQ increased also in tube-fed piglets, the differences were no more significant. Later, the RQ was maintained on a higher level which was approximately the same in both groups of piglets.

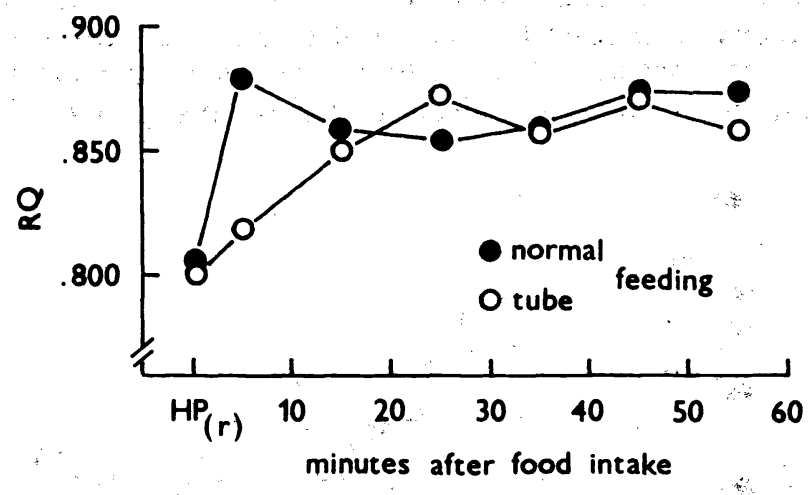

Fig. 7 Postprandial changes in RQ in differently fed piglets

\section{Discusion}

The thermic effect of food is very difficult to determine in some animals. $\mathrm{D}$ a $\mathrm{u} \mathrm{n}$ c e y and I $\mathrm{g} \mathrm{r} \mathrm{a} \mathrm{m} \mathrm{(1979),} \mathrm{for} \mathrm{example,} \mathrm{reported} \mathrm{that} \mathrm{even} \mathrm{the} \mathrm{preparation}$ of food could increase HP in pigs in the same way as feeding itself. The conditioned stimulations and especially motor activity associated with the waiting for food and its intake give false results of the measurements.

Both methods of food administration to the experimental piglets were elaborated so as to reduce these effects as much as possible. They were eliminated in such a way that the measurement of HP were done during sleep.

The present results show that the differences in the initial phase of postprandial HP between the two groups of piglets with different mode of feeding were found to be very distinct. The HP of bottle-fed piglets increased immediately after feeding, the peak value being within about 10 minutes, i. e. $30 \%$ higher than the HP during rest. In the tube-fed piglets the HP remained virtually unchanged over the same period. D i a m ond and L e B l a n c (1987ab) give similar results for dogs where the HP increased by $85 \%$ above the value of preprandial HP within 15 minutes of oral feeding, while the increase was negligible in tube-fed dogs. This initial cephalic phase lasted 45 minutes and was caused by gustatory, olfactory and tactile stimulations during normal feeding. These impulses were absent in tube-fed dogs and so no cephalic increase in HP occurred.

Basing on these data, we can evaluate the differences found in the present study between the two differently fed groups of piglets. The observed increase rate in HP after oral feeding of the piglets allows the presumption that it could not be the effect of the processes of digestion and resorption of the food. D i a m o nd and Le B I a n c (1987b) reported that catecholamines play an important role in the regulation of postprandial HP increase. However, in 
young piglets, adrenalin and noradrenalin cause only a low metabolic response (Le B I a c and Mount 1968). This could explain the relatively low, i. e. $30 \%$, cephalic increase in HP in our piglets as compared with an $85 \%$ increase in dogs. However, the rates of fading away of the cephalic phase also differed. In dogs it lasted $45 \mathrm{~min}$, whereas in our experimental piglets it reached hardly half of this time. This fact is undoubtedly connected also with the amount of consumed food, its composition, different intensity of energy metabolism of the two species compared, etc. However, another factor should be mentioned that considerably reduced the early postprandial phase of HP in piglets, i. e. REM sleep. In tube-fed piglets the effect of REM sleep was not significant, demonstrating that it is effective especially during the cephalic phase.

In previous studies on piglets we found regular decrease of their HP during REM sleep. Under cold conditions this reduction is acute, what is associated with the blocking of shivering thermogenesis, in thermally neutral conditions it is slight ( $\mathrm{K}$ o t r bá č e $\mathrm{k}$ and $\mathrm{H}$ ö n i g 1989a). In addition, the fact that the heart and respiratory rates decrease in REM sleep shows that it affects the autonomic nervous system ( $\mathrm{K}$ o $\mathrm{r} \mathrm{r}$ a a c c e $\mathrm{k}$ et. al. 1986). If REM sleep significantly reduced HP in the cephalic phase, stimulated by the automatic nervous system, we can assume, that it was the result of its suppressing effect on this system. What does it mean from the energetic point of view? The cephalic postprandial increase in HP was found to be relatively low and short-term in the experimental piglets. However, frequent food intake causes its regular repetition, thus also a gradual summation of energy expenditure. In addition, other factors may stimulate postprandial thermogenesis under natural conditions, i. e. cold exposure during sucking or competition for feed among the piglets. Hence REM sleep is all the more important for reducing energy expenditure.

The favourable effect of comfortable thermal conditions on the growth of piglets in the early postnatal period is well known. This effect is usually associated with a minimization of thermoregulatory expenditures. The energy-saving effect of REM sleep, which is also closely associated with thermal comfort, is believed to be a part of this effect. The amount of REM sleep in piglets kept under cold conditions rapidly decreases and the onset of REM episodes after food intake is delayed ( $\mathrm{K}$ o $\mathrm{tr}$ b á $\check{c}$ e $\mathrm{k}$ and $\mathrm{H}$ ö $\mathrm{n} \mathrm{i} \mathrm{d} \mathrm{1989a).} \mathrm{So} \mathrm{that} \mathrm{the} \mathrm{early} \mathrm{postprandial} \mathrm{increase} \mathrm{in} \mathrm{HP}$ is not suppressed due to the absence of REM sleep. On the one hand, this is in accordance with increased thermoregulatory expenditure, on the other hand, less energy is left for growth.

From the present results it can be concluded that REM sleep suppresses postprandial thermogenesis that evidently enables the young piglets a more effective use of the feed energy. This effect can be expected to be proportional to the stimulation of the autonomic nervous system during feeding. The condition is thermal comfort enabling a timely onset and repetition of REM sleep episodes. 


\section{REM spánek tlumi postprandisíní vzestup tepelné produkce selat}

U 3 až 5denních selat plemene bílého ušlechtilého, spících v termoneutrálním prostředí jsme sledovali vývoj tepelné produkce (TP) v prüběhu 60 minut po př́ijmu diety. Měrení byla prováděna u skupiny 10 selat krmených per os a u skupiny krmené pomocí permanentní sondy zavedené do žaludku. Abychom vyloučili vliv svalové aktivity na $\mathrm{TP}$, dieta byla podávána př́mo $\mathrm{v}$ metabolické respirační komoře selatủm zcela klidným. Kvalita i množství podávané diety bylo stejné $\mathrm{v}$ obou pokusných skupinách.

U selat krmených per os došlo $\mathrm{k}$ signifikantnímu vzestupu postprandiální TP již v prvých 10 minutách po nakrmení. Tento časný vzestup chyběl u selat krmených sondou, což svědčlo o vlivu smyslové stimulace na prủběh časné postprandiální TP.

Úroveň TP byla dále ovlivněna charakterem spánku pokusných selat. V REM spánku docházelo ve srovnání s NREM spánkem $\mathrm{k}$ jejímu pravidelnému poklesu. Pokles byl však prúkazný jen u selat krmených per os, a to v obdobi 40 minut po př́jmu krmiva.

Mechanismus tohoto energii šetřícího účinku REM spánku lze žejmě hledat $v$ jeho tlumivém vlivu na přijmem potravy stimulovaný sympatikus.

\section{REM-cö приглушает постпрандиальое увеличение теплопродукции} nopocxt

У белых породистных поросят в возрасте 3-5 суток, спящих в термонейтральной среде, проводили исследования теплопродукции (ТП) в течение 60' после приема диеты. Исследования проводили с группой 10 поросят, кормленных перорально, и с группой, кормленной с помощью постоянного зонда, введенного в желудок. Чтобы исключить влияние мышечной активности на ТП, диету давали непосредственно в метаболической респираторной камере поросятам в полном состоянии покоя. Качество и количество подаваемой диеты было одинаковым у обеих подопытных групп.

У перорально кормленных поросят наблюдалось явное увеличение постпрандиальной ТП уже в первые 10' после кормления. Данного раннего увеличения не было у поросят, кормленных зондом, что свидетельствует о влиянии чувственной стимуляции на ход ранней постпрандиальной ТП.

На уровень ТП влиял также характер сна подопытных поросят. В ходе REM-сна по сравнению с NREM-сном происходило ее регулярное понижение. Однако понижение стало явным лишь у перорально кормленных поросят, а именно через 40' после приема пищи.

Механизм данного берегущего энергию воздействия REM-сна следует, видимо, искать в его тормозящем влиянии на приемом пищи стимулированную симпатическую первовую систему. 


\section{References}

ANDREW, J. F. - DONNE, B.: 24th oxygen consumption of rats stimulated by cafeteria feeding. Proc. Nutr. Soc. 43, 1982: 36 A.

CESNEK, J. - NOVÁK, L.: Electrical katathermometer, its construction and some examples of its use in physiological experiment. Physiol. bohemoslov., 20, 1971: 57.

DAUNCEY, M. J. - INGRAM, D. L.: Effect of dietary composition and cold exposure on non-shivering thermogenesis in young pigs and its alternation by the beta-blocker propranolol. Br. J. Nutr., 41, 1979: 361-370.

DIAMOND, P. - BRONDEL, L. - LE BLANC, J.: Palatability and postprandial thermogenesis in dogs. Am. J. Physiol. 248, 1985: E75-E79.

DIAMOND, P. - LE BLANC, J.: Role of autonomic nervous system in postprandial thermogenesis in dogs. Am. J. Physiol. (Endocrinol. Metab. 15), 252, 1987a: E719-E726.

DIAMOND, P. - LE BLANC, J.: Hormonal control of postprandial thermogenesis in dogs. Am. J. Physiol. 253, 1987b: E521-E529.

HERVEY, G. R. - TOBIN, G.: Luxusconsumption, diet-induced thermogenesis and brown fat. a critical review. Clin. Sci., 64, 1983:7-18

KOTRBÁCEK, V. - NAU, H.-R. - LYHS, L.: Einfluss ausgewählter thermischer Umweltbedingungen auf den Schlaf beim neugeborenen Ferkel. Abstracts of Papers, IV. International Symposium, Ontogenesis of Farm Animals, Brno, 1986, p. 9.

KOTRBÁCEK, V. - HÖNIG, Z.: Thermal environment, sleep and energy metabolism in piglets. Acta vet. Brno, 58, 1989:000-000.

LE BLANC, J. - MOUNT, L. E.: Effects of noradrenaline and adrenaline on oxygen consumption rate and arterial blood pressure in the new-born pig. Nature, 217, 1968: 77-78.

LE BLANC, J. - BRONDEL, L.: Role of palatability on meal induced thermogenesis in human subjects. Am. J. Phyhsiol. 248: E333-E336, 1985.

ROTHWELL, N. J. - STOCK, J.: A paradox in the control of energy intake in the rat. Nature 273, 1978: 146-147.

ROTHWEL, N. J. - STOCK, J.: Energy expenditure of cafeteria-fed rats determined from measurement of energy balance and indirect calorimetry. J. Physiol. (London), 328, 1982: 371-377.

ROTHWELL, N. J. - STOCK, J.: Luxusconsumption, diet-induced thermogenesis and brown fat: a case in favor. Clin. Sci., 64, 1983: 19-23.

TRAYHURN, P. - JONES, P. M. - MC GUCKIN, M. M. - GOODBODY, A. E.: Effects of overfeeding on energy balance and brown fat thermogenesis in obese (ob/ob) mice. Nature, 295, 1982: 323-325.

Dr. Zbynžk Hönig deceased on August 5, 1989 